\title{
Using Metal-Catalyzed Oxidation Reactions and Mass Spectrometry to Identify Amino Acid Residues Within $10 \AA$ of the Metal in Cu-Binding Proteins
}

\author{
Juma D. Bridgewater, Jihyeon Lim*, and Richard W. Vachet \\ Department of Chemistry, University of Massachusetts, Amherst, Massachusetts, USA
}

\begin{abstract}
Metal-catalyzed oxidation (MCO) reactions and mass spectrometry (MS) can be used together to determine the amino acids bound to $\mathrm{Cu}$ in a metalloprotein. Selective oxidation of only amino acids bound to $\mathrm{Cu}$ during the $\mathrm{MCO} / \mathrm{MS}$ approach relies on proper choice of the types and concentrations of the reducing and oxidizing agents. We show here that if these MCO reagent concentrations are "detuned" or varied slightly from optimal conditions, nonmetalbound amino acids close to $\mathrm{Cu}$ can also be oxidized in a controlled manner. Using $\mathrm{Cu} / \mathrm{Zn}$ superoxide dismutase as a model system, we demonstrate that amino acids up to $10 \AA$ from $\mathrm{Cu}$ can be modified as long as they are readily accessible to diffusing reactive oxygen species. UV/VIS spectroscopy and measurements of oxidation kinetics provide evidence that the protein's structural integrity around $\mathrm{Cu}$ is maintained during the detuned MCO reactions. Because this method can identify amino acids around $\mathrm{Cu}$ that have low solvent accessibility, it should complement other radical-based protein surface-mapping techniques. (J Am Soc Mass Spectrom 2006, 17, 1552-1559) @ 2006 American Society for Mass Spectrometry
\end{abstract}

$\mathrm{A}$ desire to obtain greater molecular-level detail about protein structure and protein interactions with ligands, metals, and other proteins in solution drives the continual development and refinement of measurement tools for these macromolecules. The speed and sensitivity of mass spectrometry (MS) has made it an attractive alternative to traditional protein analysis techniques. Because MS measurements occur in the gas phase, though, obtaining information about protein structure in solution relies on changing the mass of the protein or its proteolytic fragments in a structure-dependent way. To accomplish this, a variety of approaches have been used, including H/D exchange [1-3], intra- and intermolecular cross-linking [4, 5], and protein surfacing mapping via covalent labeling of amino acid side chains [6-9].

In this latter category are radical-based surface mapping or footprinting techniques, which use radicals (e.g., $\mathrm{OH})$ to modify solvent-exposed amino acids. Several ways of generating these radical species have been employed, including Fenton chemistry [10], radi-

Published online July 26, 2006

Address reprint requests to Dr. R. W. Vachet, Department of Chemistry, University of Massachusetts, 701 Lederle Graduate Research Tower, 710 North Pleasant St., Amherst, MA 01003-936. E-mail: rwvachet@chem. umassedu

* Current address: Department of Developmental and Molecular Biology, Albert Einstein College of Medicine, Jack and Pearl Resnick Campus, 1300 Morris Park Ave., Ullmann Bldg., Room 405, Bronx, NY 10461, USA. olysis of water via $\gamma$-rays or synchrotron X-rays [6, 7, 11-14], electrical discharge in the presence of $\mathrm{O}_{2}$ [1517], and photolysis of $\mathrm{H}_{2} \mathrm{O}_{2}[18,19]$. In each case, the residues that are modified after exposure to the generated radicals can be identified using tandem MS (MS/ MS), typically in conjunction with proteolytic digestion. These radical-based surface mapping experiments result in covalent modifications to amino acid side chains and, thus, they are complementary to H/D exchange methods that probe protein backbone structure. Moreover, the nature of the modification in the radical-based approaches offers an advantage over H/D exchange methods because the radical reactions result in covalent modification and back exchange is not possible. There exists a disadvantage, however, as the probe (e.g., $\mathrm{OH}$ ) and the resulting modifications (e.g., $\mathrm{O}$ incorporation), are more likely to perturb protein structure than $\mathrm{D}$ incorporation.

Our group has begun to investigate a variation on these radical-based approaches that allows one to study metal interactions with proteins [20-23]. We use metalcatalyzed oxidation (MCO) reactions to generate reactive oxygen species (ROS) at a redox-active metal that is bound to a peptide or protein (Figure 1). If the MCO reagents and their concentrations are properly chosen, only the amino acid residues bound to the metal are modified as the radicals are catalytically produced only at the metal center. Tandem MS can then be used to sequence the peptide or protein, find the modified 


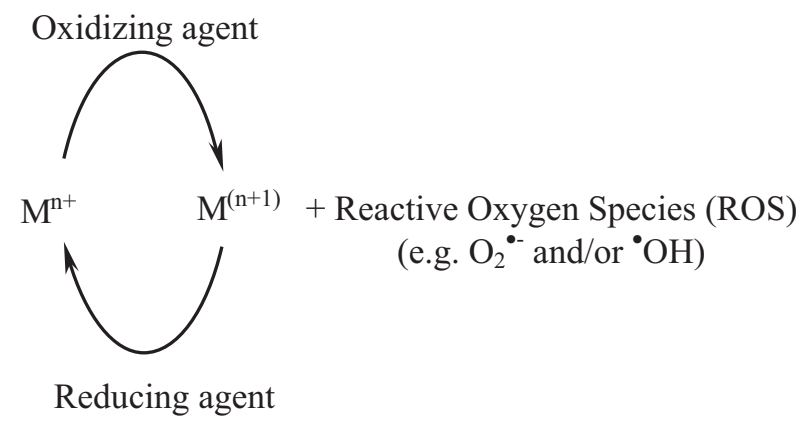

Figure 1. General reaction scheme for the production of reactive oxygen species during metal-catalyzed oxidation reactions.

residues, and thus identify the metal-binding site. Our group and other groups [24-27] have used this approach successfully to study the Cu-binding sites of several peptides and proteins, and we have recently demonstrated that the MCO/MS method can be extended to $\mathrm{Mn}, \mathrm{Fe}, \mathrm{Co}$, and Ni-binding peptides as well [28]. In an attempt to expand the protein structural information available from the MCO/MS method, we have investigated the possibility of controllably decreasing the oxidation specificity of the MCO reactions. In this report we demonstrate that if less than optimal MCO reaction conditions are chosen, both metal-bound amino acids and other nearby residues can be controllably oxidized. Such an approach offers the potential of obtaining information about the secondary coordination sphere around the metal or insight into protein structural changes that occur around the metal in response to a stimulus (e.g., ligand binding).

\section{Experimental}

\section{Materials}

$\mathrm{Cu} / \mathrm{Zn} \mathrm{SOD}$ from bovine erythrocytes, azurin from Pseudomonas aeruginosa, sodium persulfate, and Lascorbate were purchased from Sigma-Aldrich Corp (St. Louis, MO). Hydrogen peroxide (30\%), formic acid, tris(hydroxymethyl)-aminomethane (Tris), and tris(hydroxymethyl)aminomethane hydrochloride (Tris-HCl) were obtained from EM Science (Gladstone, NJ). Acetic acid and HPLC-grade acetonitrile were obtained from Fisher Scientific (Fair Lawn, NJ). Endoproteinase Asp-N and chymotrypsin were obtained from Roche Diagnostics (Indianapolis, IN), and trypsin was obtained from Promega (Madison, WI). Distilled, deionized water was generated with a Millipore (Burlington, MA) Simplicity 185 water purification system.

\section{Metal Catalyzed Oxidation (MCO) Reactions}

MCO reactions of azurin were performed at roomtemperature in solutions containing $40 \mu \mathrm{M}$ azurin, 0-100 $\mathrm{mM}$ ascorbate, $0-1 \mathrm{mM} \mathrm{H}_{2} \mathrm{O}_{2}$, and $50 \mathrm{mM}$ Tris/Tris- $\mathrm{HCl}$ buffered to $\mathrm{pH}$ 7.4. MCO reactions with $\mathrm{Cu} / \mathrm{Zn}$ SOD were performed in a water bath at $37^{\circ} \mathrm{C}$ in solutions containing $40 \mu \mathrm{M} \mathrm{Cu} / \mathrm{Zn}$ SOD, 0-100 mM ascorbate, $0-5 \mathrm{mM} \mathrm{S}_{2} \mathrm{O}_{8}^{2-}$, and $100 \mathrm{mM}$ Tris/Tris- $\mathrm{HCl}$ buffered to $\mathrm{pH}$ 7.4. In all cases the reactions were initiated by the addition of ascorbate, oxidant $\left(\mathrm{H}_{2} \mathrm{O}_{2}\right.$ or $\mathrm{S}_{2} \mathrm{O}_{8}^{2-}$ ), or both, and the total reaction time was $30 \mathrm{~min}$. In samples that were prepared for digest, the reaction was stopped by precipitating the protein with acetic and trichloroacetic acid as part of a previously described copper removal procedure [29]. After copper removal and before protein digestion, a portion of the sample was immediately either lyophilized or desalted using 10,000 Da molecular weight Centricon filters (Millipore, Bedford, MA) to remove any remaining $\mathrm{H}_{2} \mathrm{O}_{2}$ or $\mathrm{S}_{2} \mathrm{O}_{8}^{2-}$. The remaining portion of the sample was diluted to $4 \mu \mathrm{M}$ with distilled, deionized water (containing 3\% acetic acid) and analyzed by HPLC-MS immediately to determine total protein oxidation yield.

\section{Proteolytic Digests}

For $\mathrm{Cu} / \mathrm{Zn} \mathrm{SOD}$, the precipitated protein was dissolved in $115 \mu \mathrm{L}$ of $12 \mathrm{mM}$ ammonium acetate $(\mathrm{pH} 8.0)$ containing $25 \%$ acetonitrile (by volume) and $0.25 \mathrm{mM}$ DTT, and the mixture was incubated at $37^{\circ} \mathrm{C}$ for $30 \mathrm{~min}$. $4 \mu \mathrm{g}$ of trypsin and $0.4 \mu \mathrm{g}$ of endoproteinase Asp-N were each dissolved in $100 \mu \mathrm{L}$ of ammonium acetate (12 $\mathrm{mM}, \mathrm{pH}$ 8.0) and added to the dissolved protein mixture. This final mixture was incubated at $37^{\circ} \mathrm{C}$ for $16 \mathrm{~h}$. For azurin, the precipitated protein was digested overnight with $5 \mu \mathrm{g}$ of trypsin, $5 \mu \mathrm{g}$ of chymotrypsin, and 10 $\mathrm{mM}$ DTT at $37^{\circ} \mathrm{C}$ in $500 \mu \mathrm{L}$ of a $10 \mathrm{mM}$ solution of ammonium acetate buffered to $\mathrm{pH}$ 7.4. In the digestions of both proteins, the proteases were inactivated by adjusting the $\mathrm{pH}$ to 2 , and the samples were frozen until ready for further analysis. Before analysis by LC-MS or ESI-MS, the digests were diluted with distilled, deionized water and formic acid (digest/water/acid, 58.5/ $38.5 / 3.0)$.

\section{Instrumentation}

HPLC monitoring of the extent of protein oxidation was conducted using an HP 1100 (Agilent, Wilmington, DE) system with a C 8 column $(4.6 \mathrm{~mm} \times 150 \mathrm{~mm}$ Agilent, Wilmington, DE). $\mathrm{Cu} / \mathrm{Zn} \mathrm{SOD}$ was eluted with a linear gradient of acetonitrile with formic acid $(0.1 \%)$ from $10 \%$ acetonitrile/water to $90 \%$ acetonitrile/water over $10 \mathrm{~min}$ at a flow rate of $0.5 \mathrm{ml} / \mathrm{min}$. The LC effluent was split in a 1:4 ratio with the smaller outlet being fed into the ESI source of a Bruker Esquire-LC (Billerica, MA) quadrupole ion trap mass spectrometer. Typically, the needle voltage was kept at $3-4 \mathrm{kV}$, and the capillary temperature was set to $250{ }^{\circ} \mathrm{C} ; 10-60 \mathrm{~V}$ was applied to skimmer 1 , and the capillary offset voltage was set between 20 and $60 \mathrm{~V}$. For direct injection experiments similar ionization conditions were used, but sample was delivered at $1 \mu \mathrm{L} / \mathrm{min}$ using a syringe pump. 
Table 1. Residues in azurin that are oxidized under different ascorbate concentrations

\begin{tabular}{|c|c|}
\hline $\begin{array}{l}\text { Ascorbate } \\
\text { concentration, } \\
\mathrm{mM}^{\mathrm{a}}\end{array}$ & Oxidized residues (distance from $\mathrm{Cu}, \AA$ ) \\
\hline 100 & $\begin{array}{l}\text { Met44 (6.3), His } 46^{\mathrm{b}}, \text { Cys } 112^{\mathrm{b}},{\text { His } 117^{\mathrm{b}}} \text {, } \\
\text { Met121 }^{\mathrm{b}}\end{array}$ \\
\hline 10 & 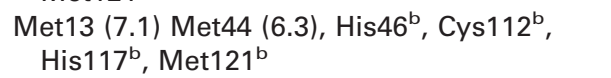 \\
\hline 5 & 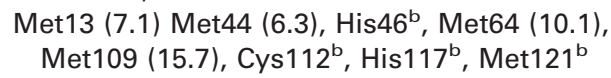 \\
\hline 0 & $\begin{array}{l}\text { Met13 (7.1) Met44 (6.3), His46 }{ }^{\mathrm{b}}, \text { Met56 (12.9), } \text {, } \\
\text { Met64 (10.1), Met109 (15.7), Cys112 } \\
\text { His117 }{ }^{\mathrm{b}}, \text { Met121 }^{\mathrm{b}}\end{array}$ \\
\hline
\end{tabular}

aThe $\mathrm{MCO}$ reactions were performed in a buffered solution at $\mathrm{pH} 7.4$ and included the indicated ascorbate concentration, $1 \mathrm{mM} \mathrm{H}_{2} \mathrm{O}_{2}$, and air.

${ }^{\mathrm{b}} \mathrm{Amino}$ acid residues that are bound to $\mathrm{Cu}$ in the native protein.

\section{Results and Discussion}

Our previous $\mathrm{MCO} / \mathrm{MS}$ studies indicate that choosing the proper ascorbate concentration is necessary to oxidize only the amino acids bound to $\mathrm{Cu}$. The actual concentrations that are necessary to maximize oxidation specificity, though, appear to depend on the degree to which the metal is buried in the peptide or protein. Typically, accurate $\mathrm{MCO} / \mathrm{MS}$ determinations of $\mathrm{Cu}-$ binding sites of peptides or proteins in which the metal site is not buried require lower ascorbate concentrations $(<10 \mathrm{mM}$ versus $100 \mathrm{mM})$ than $\mathrm{MCO} / \mathrm{MS}$ analyses of larger proteins in which the metal is buried [20-23]. Presumably, when $\mathrm{Cu}$ is not buried, lower ascorbate concentrations can effectively reduce $\mathrm{Cu}$ (II) and initiate the MCO reaction. A previous study indicates that ascorbate also plays another role, which necessitates higher concentrations for more buried $\mathrm{Cu}$ centers. It appears to scavenge radicals escaping the "cage" that is formed by the residues that are bound to the metal [22]. By minimizing the number of radicals escaping this cage, oxidation events are limited to only metal-bound amino acids. If ascorbate does indeed function as a radical scavenger and thereby limit oxidation of non$\mathrm{Cu}$-bound amino acids, a decrease in its concentration or an increase in the oxidant's concentration may result in oxidation of other amino acids near $\mathrm{Cu}$. In effect, if the MCO reactions are "detuned", modifications to other nearby amino acids could provide additional information about the protein's structure around $\mathrm{Cu}$.

\section{Azurin}

An initial test of this hypothesis was performed with the protein azurin, which was studied as a function of ascorbate concentration using $1 \mathrm{mM} \mathrm{H}_{2} \mathrm{O}_{2}$ and air as oxidants. Azurin is a $\mathrm{Cu}$-containing protein that contains six readily oxidizable methionine residues, only one of which is bound to $\mathrm{Cu}$. As we reported previously, Met44, His46, Cys112, His117, and Met121 are all oxidized under optimal or "tuned" MCO reaction con- ditions- $100 \mathrm{mM}$ ascorbate, $1 \mathrm{mM} \mathrm{H}_{2} \mathrm{O}_{2}$, and air. All the oxidized residues under these conditions are known to bind $\mathrm{Cu}$ except Met44. Because methionines are readily oxidized and Met44 is within $6 \AA$ of $\mathrm{Cu}$, it is not surprising that it is difficult to avoid oxidation of this methionine. As the ascorbate concentration is lowered in the MCO reactions, other amino acids are also found to be oxidized (Table 1 and Figure 2). The observed trend is that residues further from $\mathrm{Cu}$ are oxidized as the ascorbate concentration approaches zero. For example, at $10 \mathrm{mM}$ ascorbate Met13, which is $7 \AA$ from $\mathrm{Cu}$, is oxidized in addition to all the residues oxidized in the presence of $100 \mathrm{mM}$ ascorbate. At $5 \mathrm{mM}$ ascorbate, Met64 (10 ̊ from $\mathrm{Cu})$ and Met109 (15 ̊ from $\mathrm{Cu})$ are added to the list of oxidized residues. The correlation is not perfect, though, as Met56 is not oxidized until the ascorbate concentration is zero, even though it is closer to $\mathrm{Cu}(13 \AA)$ than Met109. Furthermore, other amino acids that readily react with hydroxyl radicals (Table 2 ) are within $10 \AA$, but none of these residues are oxidized under any of the conditions. The failure to oxidize these amino acids could be due to the presence of so many

(a)

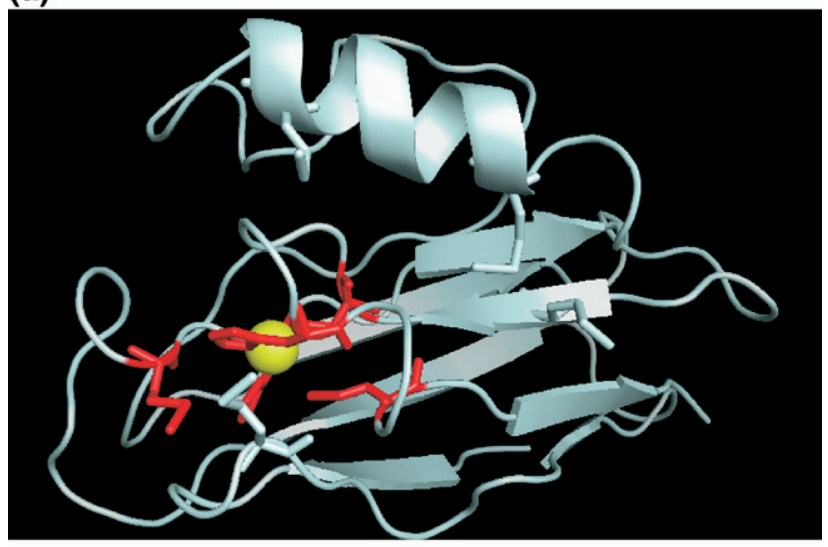

(b)

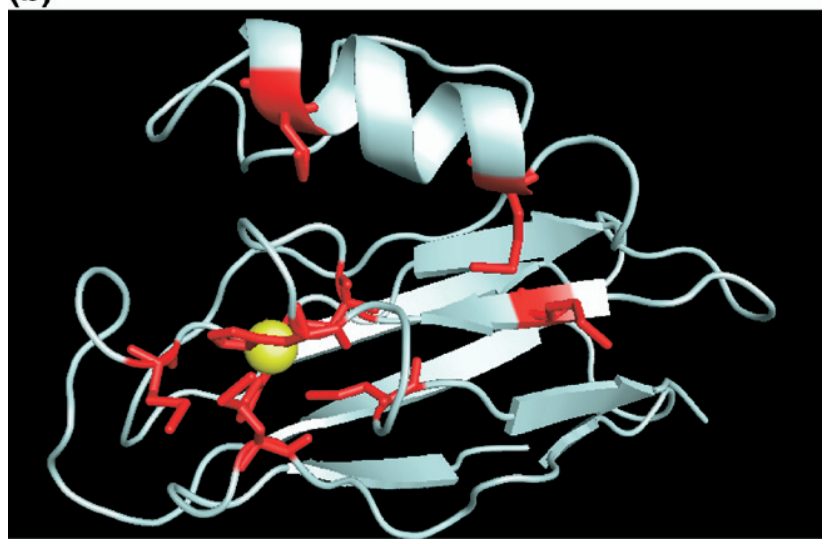

Figure 2. Structure of azurin (PDB identifier 1AZU), indicating residues oxidized under (a) fully optimized conditions and (b) detuned conditions. Copper is indicated by the yellow sphere, and the oxidized residues are shown in red. 
Table 2. Readily oxidizable amino acid residues, except methionine, in azurin that are within $10 \AA$ of $\mathrm{Cu}$ but are not found to be modified

\begin{tabular}{lc}
\hline Amino acid $^{\mathrm{a}}$ & $\begin{array}{c}\text { Distance from } \\
\mathrm{Cu}, \AA^{\mathrm{b}}\end{array}$ \\
\hline \hline Phe114 & 5.6 \\
Leu86 & 6.2 \\
His35 & 6.7 \\
Phe15 & 6.7 \\
Pro115 & 7.0 \\
Leu33 & 7.4 \\
Thr113 & 7.9 \\
Tyr72 & 8.0 \\
Ile87 & 8.5 \\
Leu120 & 8.9 \\
Phe111 & 9.4 \\
Thr84 & 9.6 \\
Trp48 & 9.6 \\
\hline
\end{tabular}

a Only amino acids that have reactions rates with ${ }^{\circ} \mathrm{OH}$ between $1 \times 10^{8}$ and $3.4 \times 10^{10} \mathrm{M}^{-1} \mathrm{~s}^{-1}$ are included [36]. This reaction rate cutoff excludes Ala, Asn, Asp, Gln, Gly, and Lys. Experimental values for isoleucine and proline are not available, but the reaction rates for these amino acids are assumed to be similar to leucine and valine, respectively.

${ }^{b}$ Not included in this list are an additional 49 readily oxidizable residues that are greater than $10 \AA$ from $\mathrm{Cu}$.

readily oxidizable Met residues; perhaps the Met residues effectively protect the other residues from oxidation. Indeed, it has been suggested previously that, via electron-transfer reactions, Met can effectively "quench" radicals initially formed at other residues, thus focusing oxidation events on Met residues [7]. Alternatively, $\mathrm{H}_{2} \mathrm{O}_{2}$ can oxidize methionine directly via a two-electron process as reported recently [30]. This direct oxidation reaction occurs much more slowly than the metal-catalyzed one, however, and the previously observed effect occurred after peptide/protein storage for two days [30]. In our experiments, the relatively low amount of $\mathrm{H}_{2} \mathrm{O}_{2}$ (i.e., $1 \mathrm{mM}$ ) is removed immediately by lyophilization or desalting after the MCO reaction is quenched. Despite these possibilities, failure to oxidize other non-Cu-bound amino acids is difficult to fully rationalize in the context of what is known about the reactions between ROS and amino acids. Previous systematic investigations of the reactivity of ROS with free amino acids or amino acids in peptides/proteins have mostly involved production of hydroxyl radicals at "random" locations in solution either via radiolysis of water [6, 7, 12-15, 31, 32] or via Fenton reactions involving $\mathrm{Fe}[32,33]$. In the current experiments, ROS are generated at a specific site within the protein and protein-bound $\mathrm{Cu}$ is the catalyst for the production of these species. Given the differences in reaction conditions, it is reasonable to expect that trends in amino acid oxidation may differ.

\section{$\mathrm{Cu} / \mathrm{Zn} S O D$}

To more carefully study the oxidation of non-Cu-bound amino acids near the metal center and thus assess the analytical utility of these detuned reactions, we decided to study another $\mathrm{Cu}$-binding protein- $\mathrm{Cu} / \mathrm{Zn}$ superoxide dismutase (SOD). While providing some useful initial results, azurin is a poor model protein in the current context. Because of its six Met residues, reproducible data is difficult to obtain as variations in electrospray conditions, trace metal concentrations in solutions, or sample age can result in significant changes to background Met oxidation from one experiment to the next. $\mathrm{Cu} / \mathrm{Zn}$ SOD has only one Met residue, so background oxidation is minimal. Moreover, we have already demonstrated that the amino acids bound to $\mathrm{Cu}$ in this protein can be specifically oxidized under the appropriate $\mathrm{MCO}$ reaction conditions. Just as in the case of azurin, a relatively high concentration of ascorbate is necessary to maximize the oxidation specificity during the $\mathrm{MCO}$ reactions of $\mathrm{Cu} / \mathrm{Zn}$ SOD. The presence of 100 $\mathrm{mM}$ ascorbate, $1 \mathrm{mM} \mathrm{S}_{2} \mathrm{O}_{8}^{2-}$, and air results in oxidation of only His44, His46, His61, and His118, which are the residues bound to $\mathrm{Cu}$. Presumably, the high concentration of ascorbate enables it to serve the dual role of reducing agent and radical scavenger so that high oxidation specificity is obtained. Because of the dual role performed by ascorbate, we investigated varying the oxidant concentration as a means of detuning the MCO reactions instead of varying the ascorbate concentration. We hypothesized that this would enable us to more controllably increase the production of ROS at the $\mathrm{Cu}$ center and thus oxidize additional residues.

Table 3. Readily oxidizable amino acid residues within $10 \AA$ of $\mathrm{Cu}$ in $\mathrm{Cu} / \mathrm{Zn} \mathrm{SOD}$, and the status of their oxidation under the detuned MCO reaction conditions

\begin{tabular}{lcc}
\hline Amino acid $^{\mathrm{a}}$ & $\begin{array}{c}\text { Distance from } \\
\text { Cu, } \AA^{\mathrm{b}}\end{array}$ & $\begin{array}{c}\text { Modified } \\
\text { (yes/no)? }\end{array}$ \\
\hline \hline His46 & 2.0 & Yes \\
His118 & 2.0 & Yes \\
His44 & 2.1 & Yes \\
His61 & 3.2 & Yes \\
Val116 & 4.4 & No \\
Arg141 & 6.2 & Yes \\
Phe43 & 6.2 & No \\
Pro60 & 6.5 & Yes \\
His69 & 6.6 & Yes \\
His78 & 7.5 & Yes \\
Met115 & 8.0 & Yes \\
Val117 & 8.5 & No \\
Ser140 & 8.5 & No \\
Val45 & 8.5 & No \\
Phe62 & 9.0 & Yes \\
\hline
\end{tabular}

a Only amino acids that have reactions rates with ${ }^{\circ} \mathrm{OH}$ between $1 \times 10^{8}$ and $3.4 \times 10^{10} \mathrm{M}^{-1} \mathrm{~s}^{-1}$ are included [36]. This reaction rate cutoff excludes Ala, Asn, Asp, Gln, Gly, and Lys. Experimental values for isoleucine and proline are not available, but the reaction rates for these amino acids are assumed to be similar to leucine and valine, respectively.

${ }^{b}$ Not included in this list are an additional 64 readily oxidizable residues that are greater than $10 \AA$ from $\mathrm{Cu}$.

${ }^{\mathrm{c}} \mathrm{A}$ peptide fragment corresponding to [Thr135-Arg141 - 43] ${ }^{+}$is observed, but its ion abundance is too low to confirm the modification at Arg141; however, a neutral loss of 43 is a common oxidative modification for Arg-containing peptides [37, 38].

${ }^{\mathrm{d}} \mathrm{MS} / \mathrm{MS}$ of the peptide fragment containing Pro60 and Phe62 is unable to clearly distinguish which of these two residues is oxidized. 


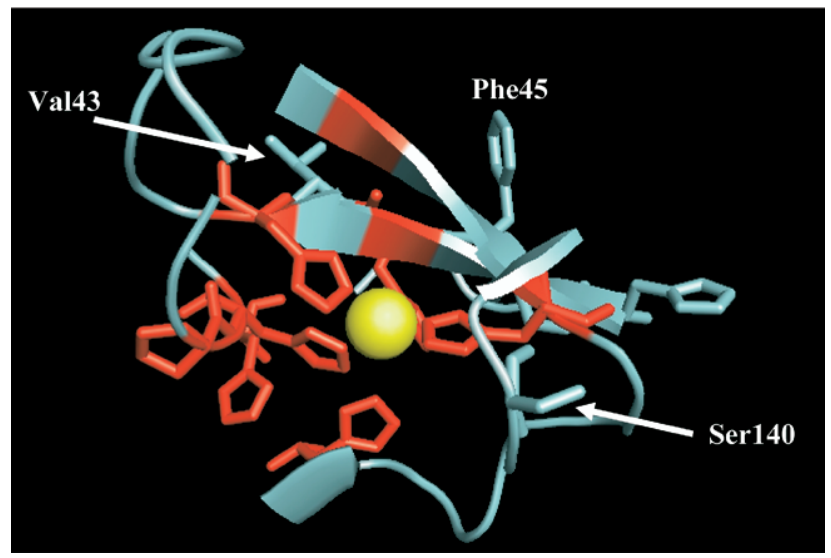

Figure 3. A view of the copper binding site of $\mathrm{Cu} / \mathrm{Zn} \mathrm{SOD}$ (PDB identifier 1E9P), indicating the amino acid residues oxidized under the detuned MCO reaction conditions. The oxidized residues are shown in red. For clarity, not all side chains are shown, nor is the entire protein shown.

As the $\mathrm{S}_{2} \mathrm{O}_{8}^{2-}$ concentration is increased above $1 \mathrm{mM}$, non-Cu-bound amino acids become modified. These residues include Pro60 (and/or Phe62), His69, His78, Met115, and Arg141, each of which is within $10 \AA$ of $\mathrm{Cu}$. Table 3 lists these and additional residues within $10 \AA$ of $\mathrm{Cu}$. From the list in Table 3, clearly not all the residues near $\mathrm{Cu}$ are oxidized. Specifically, Phe43, Val45, Val116, Val117, and Ser140 are not oxidized despite being close to $\mathrm{Cu}$. Reasonable explanations, however, can be provided for why these residues are not oxidized during the detuned MCO experiments. Phe43 and Val45 are not readily accessible to any ROS diffusing from the $\mathrm{Cu}$ center. A view of the $\mathrm{Cu}$ binding site of $\mathrm{Cu} / \mathrm{Zn}$ SOD (Figure 3) shows that the protein backbone that includes two of the binding His residues, His44 and His46, sterically hinders the approach of ROS to Phe 43 and Val45. A similar rationale can also be used to explain the failure to oxidize Val117 and Ser140. The side chains of these residues point away from the metal center and access to them is blocked by the protein backbone. It is well established that the protein backbone reacts much more slowly with ROS than amino acid side chains [31], which is consistent with the failure to observe any backbone modifications or cleavages. The side-chain of Val116, in contrast, points toward the metal, but its relatively low reactivity with hydroxyl radicals and proximity to a readily oxidizable residue (Met115) make it unlikely to be oxidized to a measurable extent.

Finding conditions that allow oxidation of binding and nearby non-binding residues is encouraging, as it suggests that protein structure around $\mathrm{Cu}$ might be accessible by a detuned MCO/MS approach; however, an important question arises. Is the additional oxidation due to freely diffusible radicals or has the $\mathrm{Cu}$ binding site been disrupted so that non-binding residues are oxidized? For the oxidation events to be most meaningful, the protein structure and $\mathrm{Cu}$-binding site should remain intact during the $\mathrm{MCO}$ reactions. To test whether changes to protein structure or $\mathrm{Cu}$-binding site account for the additional oxidation observed at higher $\mathrm{S}_{2} \mathrm{O}_{8}^{2-}$ concentrations, two sets of experiments were performed.

\section{UV-VIS Absorbance Spectroscopy}

In a first set of experiments, we considered two spectroscopic techniques that are sensitive to metal binding sites. Electron paramagnetic resonance (EPR) and ultravioletvisible (UV-VIS) absorbance spectroscopies have been used to study the active site of $\mathrm{Cu} / \mathrm{Zn} \mathrm{SOD}[34,35]$. Both of these techniques can provide information about the ligand environment around $\mathrm{Cu}$, and thus they might indicate any structural changes around $\mathrm{Cu}$ or any disruption of the $\mathrm{Cu}$ binding site during the MCO reactions. Unfortunately, EPR does not provide much useful information (data not shown) because the presence of such a high ascorbate concentration greatly weakens the EPR signal for $\mathrm{Cu}(\mathrm{II})$. UV-VIS absorbance measurements, on the other hand, do provide some insight into the effect (or lack thereof) of the MCO reagents on the integrity of the $\mathrm{Cu}$ binding site. In particular, two spectral features are informative. The first absorbance feature with a $\lambda_{\max } \approx$ $660 \mathrm{~nm}$ can be used to monitor the $\mathrm{Cu}$ (II) binding site as it corresponds to a d-d transition for $\mathrm{Cu}$ (II). The second absorbance feature is a ligand-to-metal charge-transfer band involving His61 and $\mathrm{Cu}(\mathrm{II})$ and has a $\lambda_{\max } \approx 420 \mathrm{~nm}$. His61 bridges $\mathrm{Cu}(\mathrm{II})$ and $\mathrm{Zn}(\mathrm{II})$, and previous studies have used the band at $420 \mathrm{~nm}$ to indirectly monitor the $\mathrm{Zn}$ (II) binding site [34, 35]. The specific utility of these two features comes from the ability to monitor changes in their intensity and/or $\lambda_{\max }$ values as a function of time after exposure to the MCO reagents.

During the course of the $\mathrm{MCO}$ reaction with $100 \mathrm{mM}$ ascorbate and $3 \mathrm{mM} \mathrm{S}_{2} \mathrm{O}_{8}^{2-}$, the $660 \mathrm{~nm}$ band decreases

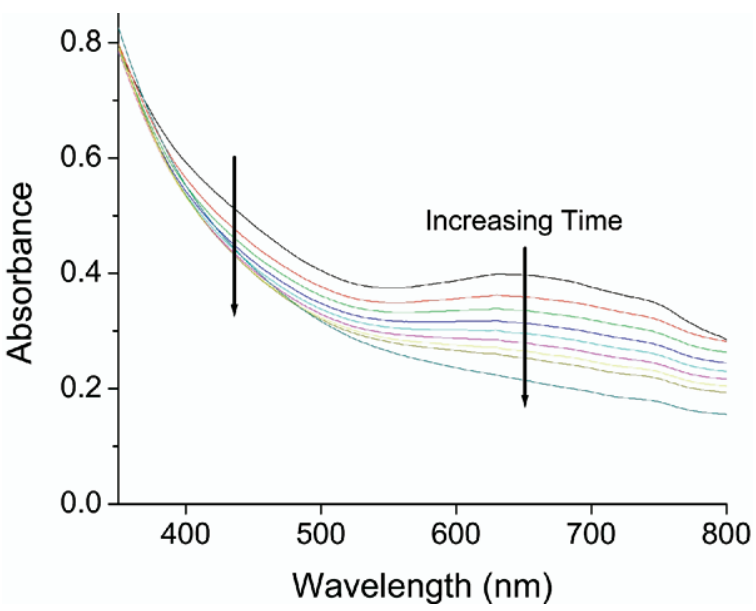

Figure 4. UV/VIS spectra of $\mathrm{Cu} / \mathrm{Zn} \mathrm{SOD}$ as a function of time at $\mathrm{pH}=7.4$ in the presence of $100 \mathrm{mM}$ ascorbate and $3 \mathrm{mM} \mathrm{S}_{2} \mathrm{O}_{8}^{2-}$. Spectrum acquisition began as soon as ascorbate and $\mathrm{S}_{2} \mathrm{O}_{8}^{2-}$ were added and continued for $15 \mathrm{~min}$. The arrows on the graph indicate the absorbances at 420 and $660 \mathrm{~nm}$ that were monitored. 
over time as $\mathrm{Cu}(\mathrm{II})$ is reduced to the spectroscopically silent $\mathrm{Cu}(\mathrm{I})$ species (Figure 4). The $\lambda_{\max }$ value of this peak remains essentially unchanged as its intensity decreases, which suggests $\mathrm{Cu}$ maintains its normal binding site. As the absorbance at $660 \mathrm{~nm}$ is decreasing, the intensity of the feature at $420 \mathrm{~nm}$ is also decreasing at a very similar rate. Indeed, the rate constants for the disappearances of these two features are close $(9.6 \pm 0.2$ $\times 10^{-4} \mathrm{~s}^{-1}$ at $660 \mathrm{~nm}$ versus $5.0 \pm 0.4 \times 10^{-4} \mathrm{~s}^{-1}$ at 420 $\mathrm{nm})$. Two possibilities can be invoked to explain the loss of the absorbance feature at $420 \mathrm{~nm}$. The first explanation is reduction of $\mathrm{Cu}(\mathrm{II})$ to $\mathrm{Cu}(\mathrm{I})$, which eliminates the ligand-to-metal charge-transfer band at 420 $\mathrm{nm}$, and the second explanation is the protonation of His61 that occurs upon release of $\mathrm{Zn}$ (II). Indeed, this latter occurrence has been used to demonstrate the greater lability of the $\mathrm{Zn}$ binding site compared with the $\mathrm{Cu}(\mathrm{II})$ binding site in this enzyme [34, 35]. It is known that upon perturbation of the active site, $\mathrm{Zn}$ (II) is released much more readily than $\mathrm{Cu}(\mathrm{II})$. The very similar kinetics of these two absorbance features suggest that the integrity of the $\mathrm{Zn}$ (II) site is maintained, and the decreased absorbance at $420 \mathrm{~nm}$ reflects $\mathrm{Cu}$ (II) reduction only. If $\mathrm{Zn}$ (II) were lost during the MCO reactions, one would expect it to be lost more readily than $\mathrm{Cu}$ and the absorbance at $420 \mathrm{~nm}$ would decrease more rapidly than the absorbance at $660 \mathrm{~nm}$.

Two conclusions that have an impact on our detuned $\mathrm{MCO} / \mathrm{MS}$ studies can be drawn from this absorbance data. First, the $\mathrm{Cu}$ (II) binding site is not disrupted by the presence of the MCO reagents. If it were disrupted, one would expect a noticeable shift in the $\lambda_{\max }$ around $660 \mathrm{~nm}$, but no significant shift is observed. This observation suggests that oxidation of non-Cu-bound residues is not due to the formation of new $\mathrm{Cu}$ (II)-binding sites. Second, the $\mathrm{Zn}$ (II) binding site is not disrupted by the presence of the $\mathrm{MCO}$ reagents. If the $\mathrm{MCO}$ reagents do cause the displacement of $\mathrm{Zn}$ (II), we would expect a different disappearance rate for the $420 \mathrm{~nm}$ feature as $\mathrm{Zn}$ is released more rapidly than $\mathrm{Cu}$. The significance of this second conclusion is that oxidations of His69 and His78, which are bound to $\mathrm{Zn}(\mathrm{II})$, are not likely to be due to migration of $\mathrm{Cu}$ (II) to the $\mathrm{Zn}$ (II) binding site. While the observed changes to these spectral features argue that the integrity of the binding site is retained during the detuned MCO reactions, the lack of spectral features for $\mathrm{Cu}(\mathrm{I})$ leaves some ambiguity. The absorbance data do not provide any direct information about the fate of $\mathrm{Cu}(\mathrm{I})$ after it is formed by reduction of $\mathrm{Cu}(\mathrm{II})$. Migration of $\mathrm{Cu}(\mathrm{I})$ to other amino acid residues, its transient reoxidation to $\mathrm{Cu}(\mathrm{II})$, and the subsequent production of ROS could possibly explain oxidation of the non-bound residues. To eliminate this ambiguity, a second set of experiments was performed.

\section{Oxidation Kinetics}

The second set of experiments involved determining the oxidation kinetics of each of the residues that were

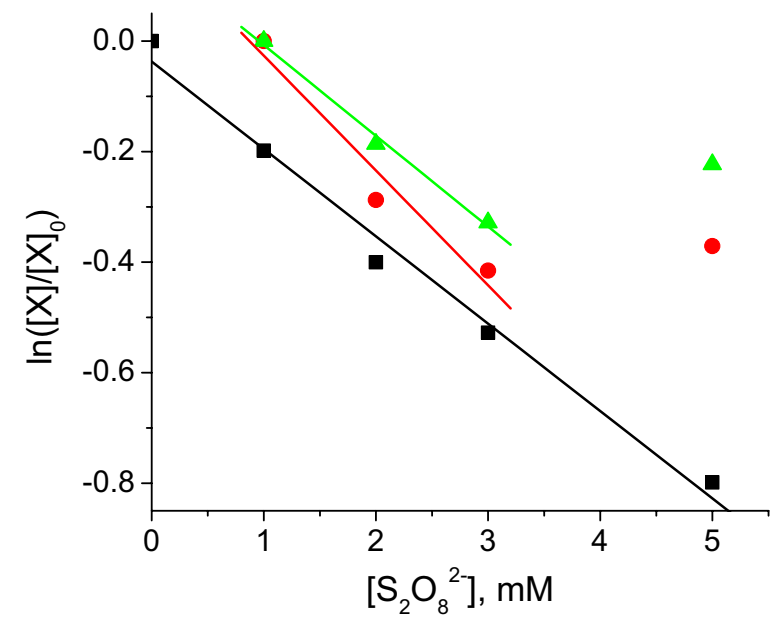

Figure 5. Pseudo first-order plot of the change in unmodified peptide as a function of $\mathrm{S}_{2} \mathrm{O}_{8}^{2-}$ concentration. The data for the peptide fragment Lys68-Lys73, which contains non-Cu bound His69, is represented by filled triangles, the data for His78-Ala87, which contains non-Cu bound His78, is represented by filled circles, and the data for Asp40-Gly49, which contains the $\mathrm{Cu}-$ binding residues His44 and His46, is represented by filled squares.

modified during the detuned MCO experiments. As with the regular MCO reactions, the detuned reactions follow pseudo first-order kinetics, so the observed oxidation rate constant $\left(k_{\mathrm{o}}\right)$ for a given amino acid or peptide is related to the "real" rate constant $\left(\mathrm{k}_{\mathrm{r}}\right)$ by eq 1 , where $C$ is a constant that accounts for the impact of the excess ascorbate on the real rate constant, $[\mathrm{Ox}]$ is the concentration of the oxidizing agent, and $t$ is time. The extent of

$$
k_{0}=C k_{r}[O x] t
$$

oxidation for an amino acid (or a peptide containing that amino acid) at a fixed reaction time can be readily monitored as a function of $[\mathrm{Ox}]$ concentration, and this data can be used to assess whether or not the integrity of the binding site is maintained. During these experiments, we make the same assumption that is made in other methods where radicals are used to probe protein (or DNA) structure-as long as the protein's structure remains the same, in this case its structure around $\mathrm{Cu}$, pseudo first-order kinetics will be preserved [7]. If structural integrity is lost, the dynamics (e.g., activation energy) of the oxidation reaction at any given amino acid will change and deviations from pseudo first-order kinetics will be evident.

The extent of peptide oxidation as a function of $\mathrm{S}_{2} \mathrm{O}_{8}^{2-}$ concentration has been monitored for each of the peptides that contain the oxidized residues shown in Table 3. Figure 5 shows the pseudo first-order kinetic plots for three of these peptides-Lys68-Lys73, which contains His69, His78-Ala87, which contains His78, and Asp40-Gly49, which contains His44 and His46. This plot clearly indicates that pseudo first-order kinetics are maintained as long as the $\mathrm{S}_{2} \mathrm{O}_{8}^{2-}$ concentration is $3 \mathrm{mM}$ 
or below. At concentrations between 0 and $3 \mathrm{mM}$, each of the three plots is linear, indicating that the dynamics of the oxidation reactions are constant. At $5 \mathrm{mM} \mathrm{S}_{2} \mathrm{O}_{8}^{2-}$, the linearity of these first-order plots deviates significantly for Lys68-Lys73 and His78-Ala87, suggesting some change in their positioning relative to $\mathrm{Cu}$ or some change in a neighboring region that affects the rate of oxidation of these peptides. Even though the plot for Asp40-Gly49 is still linear at $5 \mathrm{mM} \mathrm{S}_{2} \mathrm{O}_{8}^{2-}$, deviations for the other peptide sequences indicate that the detuned conditions only provide meaningful information when the $\mathrm{S}_{2} \mathrm{O}_{8}^{2-}$ concentration is maintained at $3 \mathrm{mM}$ or below. Because the data in Figure 5 is consistent with the UV-VIS absorbance data, we feel confident that the detuned $\mathrm{MCO}$ reactions at or below $3 \mathrm{mM}$ concentrations of $\mathrm{S}_{2} \mathrm{O}_{8}^{2-}$ provide information about protein structure near $\mathrm{Cu}$ without disrupting the binding site.

\section{Conclusions}

By varying the $\mathrm{MCO}$ reaction conditions used during oxidation of a $\mathrm{Cu}$-bound protein, we demonstrate that non-metal-bound amino acid residues can be oxidized and then identified by MS. Using $\mathrm{Cu} / \mathrm{Zn}$ SOD as a model system, we show that amino acids within about $10 \AA$ of $\mathrm{Cu}$ can be oxidized when the oxidant concentration is increased beyond an optimum level. Close examination of the known structure around $\mathrm{Cu}$ suggests that only those residues that are readily accessible to diffusing ROS are modified. Any amino acid side chains that are hindered either by the protein backbone or by other side chains remain unmodified even though they are within $10 \AA$ of $\mathrm{Cu}$. Evidence that the nonbound residues are modified by diffusible ROS instead of changes to the $\mathrm{Cu}$ binding site is provided by both UV-VIS spectroscopy and measurements of oxidation kinetics. In analogy to other radical-based protein footprinting methods, pseudo first-order oxidation kinetics are used to indicate that the $\mathrm{Cu}$-binding site has maintained its integrity.

Further work on other model systems is necessary to more fully assess the potential of this detuned $\mathrm{MCO} / \mathrm{MS}$ method. More work on proteins such as azurin that contain numerous methionine residues will be particularly important as an abundance of this residue could complicate the described experiments. Even so, this approach might serve as a complementary method to other radical-based footprinting approaches that provide information about surface exposed amino acids. Unlike the radical-based methods that probe protein surface structure with radicals generated at random locations in solution, the current approach can provide a three-dimensional reference point for protein structure because radicals are generated at a single site (i.e., $\mathrm{Cu}$ ) within the protein structure. Furthermore, because many amino acid residues close to metal centers have low solvent accessibility, the detuned $\mathrm{MCO} / \mathrm{MS}$ approach can provide altogether new information when compared with the other surface mapping methods. Finally, the described approach might have some potential for providing information about protein structural changes around $\mathrm{Cu}$ in response to stimuli such as ligand binding or interactions with another protein.

\section{Acknowledgments}

This work was supported by a grant from the National Institutes of Health (RO1 GM075092).

\section{References}

1. Kaltashov, I. A.; Eyles, S. J. Studies of Biomolecular Conformations and Conformational Dynamics by Mass Spectrometry. Mass Spectrom. Rev. 2002, 21, 37-71.

2. Engen, J. R.; Smith, D. L. Investigating Protein Structure and Dynamics by Hydrogen Exchange MS. Anal. Chem. 2001, 73, 256A-265A.

3. Kaltashov, I. A.; Eyles, S. J. Crossing the Phase Boundary to Study Protein Dynamics and Function: Combination of Amide Hydrogen Exchange in Solution and Ion Fragmentation in the Gas Phase. J. Mass Spectrom. 2002, 37, 557-565.

4. Trakselis, M. A.; Alley, S. C.; Ishmael, F. T. Identification and Mapping of Protein-Protein Interactions by a Combination of Cross-Linking, Cleavage and Proteomics. Bioconjugate Chem. 2005, 16, 741-750.

5. Sinz, A. Chemical Cross-Linking and Mass Spectrometry for Mapping Three-Dimensional Structures of Proteins and Protein Complexes. J. Mass Spectrom. 2003, 38, 1225-1237.

6. Guan, J. Q.; Chance, M. R. Structural Proteomics of Macromolecular Assemblies Using Oxidative Footprinting and Mass Spectrometry. Trends Biochem. 2005, 30, 583-592.

7. Kiselar, J. G.; Maleknia, S. D.; Sullivan, M.; Downard, K. M.; Chance, M. R. Hydroxyl Radical Probe of Protein Surfaces Using Synchrotron X-Ray Radiolysis and Mass Spectrometry. Int. J. Radiat. Biol. 2002, 78, 101-114.

8. Zappacosta, F.; Ingallinella, P.; Scaloni, A.; Pessi, A.; Bianchi, E. Sollazzo, M.; Tramontano, A.; Marino, G.; Pucci, P. Surface Topology of Minibody by Selective Chemical Modifications and Mass Spectrometry. Protein Sci. 1997, 6, 1901-1909.

9. Suckau, D.; Mak, M.; Przybylski, M. Protein Surface Topology-Probing by Selective Chemical Modification and Mass Spectrometric Peptide Mapping. Proc. Natl. Acad. Sci. U.S.A. 1992, 89, 5630-5634

10. Sharp, J. S.; Becker, J. M.; Hettich, R. L. Protein Surface Mapping by Chemical Oxidation: Structural Analysis by Mass Spectrometry. Anal. Biochem. 2003, 313, 216-225.

11. Guan, J.; Vorobiev, S.; Almo, S. C.; Chance, M. R. Mapping the G-Actin Binding Surface of Cofilin Using Synchrotron Protein Footprinting. Biochemistry 2002, 41, 5765-5775.

12. Xu, G.; Chance, M. R. Radiolytic Modification of Amino Acid Residues in Peptides: Probes for Examining Protein-Protein Interactions. Anal. Chem. 2004, 76, 1213-1221.

13. Kiselar, J. G.; Janmey, P. A.; Almo, S. C.; Chance, M. R. Visualizing the $\mathrm{Ca}^{2+}$-Dependent Activation of Gelsolin by Using Synchrotron Footprinting Proc. Natl. Acad Sci. U.S. A. 2003, 100, 3942-3947.

14. Maleknia, S.D.; Brenowitz, M.; Chance, M. R. Millisecond Radiolytic Modification of Peptides by Synchrotron X-Rays Identified by Mass Spectrometry. Anal. Chem. 1999, 71, 3965-3973.

15. Maleknia, S. D.; Chance, M. R.; Downard, K. M. Electrospray-Assisted Modification of Proteins: A Radical Probe of Protein Structure. Rapid Commun. Mass Spectrom. 1999, 13, 2352-2358.

16. Wong, J. W.; Maleknia, S. D.; Downard, K. M. Study of the RibonucleaseS-Protein-Peptide Complex Using a Radical Probe and Electrospray Ionization Mass Spectrometry. Anal. Chem. 2003, 75, 1557-1563.

17. Maleknia, S. D.; Wong, J. W. H.; Downard, K. M.; Photochemical and Electrophysical Production of Radicals on Millisecond Timescales to Probe the Structure, Dynamics, and Interactions of Proteins. Photochem. Photobiol. Sci. 2004, 3, 741-748.

18. Sharp, J. S.; Becker, J. M.; Hettich, R. L. Analysis of Protein Solvent Accessible Surfaces by Photochemical Oxidation and Mass Spectrometry. Anal. Chem. 2004, 76, 672-683.

19. Hambly, D. M. Gross, M. L. Laser Flash Photolysis of Hydrogen Peroxide to Oxidize Protein Solvent-Accessible Residues on the Microsecond Timescale. J. Am. Soc. Mass Spectrom. 2005, 16, 2057-2063.

20. Lim, J.; Vachet, R. W. Development of a Methodology Based on Metal-Catalyzed Oxidation Reactions and Mass Spectrometry to Determine the Metal Binding Sites in Copper Metalloproteins. Anal. Chem. 2003, 75, 1164-1172.

21. Lim, J.; Vachet, R. W. Using Mass Spectrometry to Study CopperProtein Binding Under Native and Non-Native Conditions: $\beta$-2-Microglobulin. Anal. Chem. 2004, 76, 3498-3504.

22. Bridgewater, J. D.; Vachet, R. W. Metal-Catalyzed Oxidation Reactions and Mass Spectrometry: The Roles of Ascorbate and Different Oxidizing Agents in Determining Cu-Protein-Binding Sites. Anal. Biochem. 2005, 41, 122-130. 
23. Bridgewater, J. D.; Vachet, R. W. Using Microwave-Assisted MetalCatalyzed Oxidation Reactions and Mass Spectrometry to Increase the Rate at which the Copper-Binding Sites of a Protein are Determined. Anal. Chem. 2005, 77, 4649-4653.

24. Zhao, F.; Ghezzo-Schöneich, E.; Aced, G. I.; Hong, J.; Milby, T.; Schöneich, C. Metal-Catalyzed Oxidation of Histidine in Human Growth Hormone. J. Biol. Chem. 1997, 272, 9019-9029.

25. Hovorka, S. W.; Williams, T. D.; Schöneich, C. Characterization of the MetalBinding Site of Bovine Growth Hormone Through Site-Specific Metal Catalyzed Oxidation and High-Performance Liquid Chromatography-Tandem Mass Spectrometry. Anal. Biochem. 2002, 300, 206-211.

26. Schöneich, C.; Williams, T. D. Cu(II)-Catalyzed Oxidation of $\beta$-Amyloid Peptide Targets His13 and His14 Over His6: Detection of 2-OxoHistidine by HPLC-MS/MS. Chem. Res. Toxicol. 2002, 15, 717-722.

27. Kurahashi, T.; Miyazaki, A.; Suwan, S.; Isobe, M. Extensive Investigations on Oxidized Amino Acid Residues in $\mathrm{H}_{2} \mathrm{O}_{2}$-Treated $\mathrm{Cu}, \mathrm{Zn}$-SOD Protein with LC-ESI-Q-TOF-MS, MS/MS for the Determination of the Copper-Binding Site. J. Am. Chem. Soc. 2001, 123, 9268-9278.

28. Bridgewater, J. D.; Lim, J.; Vachet, R. W. Transition Metal-Peptide Binding Studied by Metal-Catalyzed Oxidation Reactions and Mass Spectrometry. Anal. Chem. 2006, 78, 2432-2438.

29. Ambler, R. P.; Brown, L. H. The Amino Acid Sequence of Pseudomonas fluorescens Azurin. Biochem. J. 1967, 104, 784-825.

30. Xu, G.; Kiselar, J.; He, Q.; Chance, M. R. Secondary Reactions and Strategies to Improve Quantitative Protein Footprinting. Anal. Chem. 2005, 77, 3029-3037.
31. Garrison, W. M. Reaction Mechanisms in the Radiolysis of Peptides, Polypeptides, and Proteins. Chem. Rev. 1987, 87, 381-398.

32. Stadtman, E. R. Oxidation of Free Amino Acids and Amino Acid Residues in Proteins by Radiolysis and by Metal-Catalyzed Reactions. Annu. Rev. Biochem. 1993, 62, 797-821.

33. Sheldon, R. A.; Kochi, J. K. Metal Catalyzed Oxidations of Organic Compounds; Academic Press: New York, 1981.

34. Pantoliano, W. M.; McDonnell, P. J.; Valentine, J. S. Reversible Loss of Metal Ions from the Zinc-Binding Site of Copper-Zinc Superoxide. J. Am. Chem. Soc. 1979, 101, 6454-6456.

35. Pantoliano, M. W.; Valentine, J. S.; Mammone, R. J.; Scholler, D. M. $\mathrm{pH}$ Dependence of Metal Ion Binding to the Native Zinc Site of Erythrocuprein (Superoxide Dismutase). J. Am. Chem. Soc. 1982, 104, 1717-1723.

36. Buxton, G. V.; Greenstock, C. L.; Helman, W. P.; Ross, A. B. Critical Review of Rate Constants for Reactions of Hydrated Electrons, Hydrogen Atoms, and Hydroxyl Radicals in Aqueous Solution. J. Phys. Chem. Ref. Data 1988, 17, 513-886.

37. Amici, A.; Levine, R. L.; Tsai, L.; Stadtman, E. R. Conversion of Amino Acid Residues in Proteins and Amino Acid Homopolymers to Carbonyl Derivatives by Metal-Catalyzed Oxidation Reaction. J. Biol. Chem. 1989, 264, 3341-3346.

38. Xu, G.; Takamoto, K.; Chance, M. R. Radiolytic Modification of Basic Amino Acid Residues in Peptides: Probes for Examining ProteinProtein Interactions. Anal. Chem. 2003, 75, 6995-7007. 